\title{
KURIKULUM DAN PROBLEMATIKA PEMBELAJARAN BAHASA DAN SASTRA \\ INDONESIA
}

\author{
Elisa Anggraini \\ Pendidikan Bahasa dan Sastra Indonesia \\ Pascasarjana Universitas Negeri Medan
}

\begin{abstract}
ABSTRAK
Kurikulum 2013 adalah kurikulum pendidikan di Indonesia saat ini yang telah diberlakukan oleh Kementrian Pendidikan dan Kebudayaan (Kemendikbud) Indonesia. Tujuan dari kurikulum baru ini adalah untuk memajukan pendidikan serta membenahi karakter pelajar di Indonesia. Masalah pokok dalam tulisan ini difokuskan pada problematika pembelajaran bahasa dan sastra Indonesia ditinjau dari permasalahan faktor guru, siswa, dan bahan/materi ajar serta unsur media pembelajarannya. Tujuan dari penulisan ini untuk mengetahui problematika yang dihdapi guru dalam pembelajaran bahasa Indonesia dan kaitnnya dengan kurikulum. Berdasarkan tujuan, tulisan ini dapat dikatagorikan sebagai penelitian deskriptif kualitatif, yaitu mengumpulkan informasi mengenai status suatu gejala yang ada. Kemudian mendeskripsikannya sesuai data yang diperoleh di lapangan. Penulis menggali data yang dianggap sesuai dengan penelitian ini. Data yang akan digali dalam penelitian ini sebagai berikut: aspek guru dalam mengajar, yaitu data problematika guru dalam mengajar, aspek siswa, kesulitan-kesulitan siswa dalam belajar bahasa Indonesia, dan aspek materi dan media pembelajaran yang mendukung proses belajar-mengajar bahasa Indonesia.
\end{abstract}

Kata kunci: kurikulum, problematika, guru, siswa, dan media

\section{PENDAHULUAN}

Kurikulum 2013 adalah kurikulum pendidikan di Indonesia saat ini yang telah diberlakukan oleh Kementrian Pendidikan dan Kebudayaan (Kemendikbud) Indonesia. Tujuan dari kurikulum baru ini adalah untuk memajukan pendidikan serta membenahi karakter pelajar di Indonesia. Kurikulum 2013 ini mencakup beberapa mata pelajaran, salah satunya adalah bahasa Indonesia. Penerapan kurikulum baru ini diharapkan dapat membuat siswa selalu berpikir kritis dan kreatif.

Perubahan kurikulum dilakukan untuk menjawab tantangan zaman yang terus berubah agar peserta didik mampu bersaing di masa depan. Guru merupakan penentu dalam keberhasilan impelementasi kurikulum. Namun, perubahan kurikulum tidak selalu berakibat baik, apabila tidak sejalan dengan SDM yang memadai dari pelaksana kurikulum. Secanggih apapun kurikulum, tetapi apabila guru sebagai pelaksana tidak bisa menerapkannya maka kurikulum tersebut akan gagal. Dengan demikian, guru haruslah memahami konsep setiap kurikulum yang sedang diberlakukan, baik secara teoritis maupun praktis. 
Dalam dinamika kehidupan masyarakat, bangsa Indonesia dituntut untuk membekali diri dengan seperangkat kompetensi agar dapat bersaing dan tetap eksis sebagai bangsa yang mandiri di tengah percaturan global. Seperangkat kemampuan tersebut meliputi kemampuan berkomunikasi, kemampuan berpikir jernih dan kritis, kemampuan mempertimbangkan segi moral suatu permasalahan, kemampuan menjadi warga negara yang bertanggungjawab, kemampuan mencoba untuk mengerti dan toleran terhadap pandangan yang berbeda, kemampuan hidup dalam masyarakat yang mengglobal, memiliki minat luas dalam kehidupan, memiliki kesiapan untuk bekerja, memiliki kecerdasan sesuai dengan bakat/minatnya, memiliki rasa tanggung jawab terhadap lingkungan.

Untuk itu, inti dari kurikulum 2013 adalah pada upaya penyederhanaan, dan tematikintegratif. Kurikulum 2013 disiapkan untuk mencetak generasi yang siap dalam menghadapi masa depan. Oleh karena itu, kurikulum disusun untuk mengantisipasi perkembangan masa depan. Titik berat kurikulum 2013 bertujuan untuk mendorong peserta didik atau siswa agar mampu lebih baik dalam melakukan observasi, bertanya, bernalar, dan mengomunikasikan (mempresentasikan) yang mereka peroleh atau mereka ketahui setelah menerima materi pembelajaran di sekolah. Objek yang menjadi pembelajaran dalam penataan dan penyempurnaan kurikulum 2013 ini lebih menekankan pada fenomena alam, fenomena sosial, fenomena seni, dan fenomena budaya. Melalui pendekatan tersebut siswa diharapkan untuk memiliki kompetensi sikap, keterampilan, dan pengetahuan jauh lebih baik. Mereka akan lebih kreatif, inovatif, dan lebih produktif, sehingga nantinya mereka bisa sukses dalam menghadapi berbagai persoalan dan tantangan di zamannya, memasuki masa depan yang lebih baik. Atau dengan kata lain, tema pengembangan kurikulum 2013 adalah agar dapat menghasilkan insan Indonesia yang produktif, kreatif, inovatif, dan afektif melalui penguatan sikap (tahu mengapa), keterampilan (tahu bagaimana), dan pengetahuan (tahu apa) secara terintegrasi.

Kurikulum 2013 merupakan peralihan dari KTSP.Ciri khas Kurikulum 2013 yaitu pembelajarannya yang tematik integratif, menggunakan pendekatan saintifik, dan pendekatan penilaian menggunakan pendekatan otentik. Bentuk penilaian dalam kurikulum 2013 terlihat memiliki perbedaan yang cukup mendasar dengan kurikulum sebelumnya. Dengandemikian tidak semua guru memahami secara komperehensif pelaksanaan dari penilaian ontentik dalam kurikulum baru tersebut.

Adanya gema reformasi dalam sistem pendidikan, semua elemen pendidikan dituntut untuk meningkatkan kualitas diri. Tidak tertutup kemungkinan bahwa dalam proses ke arah kemajuan tersebut ditemukan pula berbagai problematika, salah satunya adalah problematika 
dalam bidang pembelajaran siswa dalam mata pelajaran bahasa Indonesia. Pelajaran bahasa Indonesia di sekolah masih menghadapi berbagai problematika, baik secara internal (diri guru dan siswa) maupun eksternal atau faktor pendukung lain dalam pembelajaran, seperti materi, metode, dan media pembelajaran.

Otonomi dalam penyelenggaraan pendidikan dan kebudayaan mempunyai implikasi dan tanggung jawab yang besar terhadap sekolah terutama guru. Hal ini menuntut guru, terutama guru bahasa Indonesia untuk lebih memiliki komptensi berbahasa Indonesia yang tinggi. Namun kenyataannya, pembelajaran bahasa masih menghadapi berbagai problema. Kenyataan seperti ini merupakan benih-benih timbulnya kendala atau problematika pembelajaran pada kurikulum 2013 secara umum dan mata pelajaran bahasa Indonesia secara khusus, sehingga perlunya penelitian ini dilakukan untuk menjawab apa saja problematika yang ada pada pembelajaran bahasa Indonesia berdasarkan kurikulum 2013. Untuk menjawab permasalahan tersebut, penelitian ini secara singkat akan menguraikan problematika dalam pembelajaran bahasa Indonesia, baik guru maupun siswa, dan materi ajarnya, khususnya terhadap bahasa Indonesia

Masalah pokok dalam tulisan ini difokuskan pada problematika pembelajaran bahasa dan sastra Indonesia ditinjau dari permasalahan faktor guru, siswa, dan bahan/materi ajar serta unsur media pembelajarannya. Bertolak dari fokus penelitian di atas, masalah penelitian ini dapat dirumuskan sebagai berikut:

1. Bagaimana gambaran permasalahan pembelajaran bahasa Indonesia ditinjau dari faktor guru yang mengajar?

2. Bagaimana gambaran permasalahan pembelajaran bahasa Indonesia ditinjau dari faktor permasalahan siswa?

3. Bagaimana gambaran permasalahan pembelajaran bahasa Indonesia ditinjau dari faktor materi pembelajaran?

\section{METODE}

Penulis tentang kurikulum dan problematika pembelajaran bahasa Indonesia ini akan diteliti dengan deskripsi artinya membuat gambaran secara sistematis mengenai beberapa hubungan yang akan diteliti. Berdasarkan tujuan, tulisan ini dapat dikatagorikan sebagai penelitian deskriptif kualitatif, yaitu mengumpulkan informasi mengenai status suatu gejala yang ada. Kemudian mendeskripsikannya sesuai data yang diperoleh di lapangan.

Penulis menggali data yang dianggap sesuai dengan penelitian ini. Data yang akan digali dalam penelitian ini sebagai berikut. 
1. Aspek guru dalam mengajar, yaitu data problematika guru dalam mengajar.

2. Aspek siswa, kesulitan-kesulitan siswa dalam belajar bahasa Indonesia.

3. Aspek materi dan media pembelajaran yang mendukung proses belajar-mengajar bahasa Indonesia.

\section{HASIL DAN PEMBAHASAN}

Pada tulisan ini, penulis mencantumkan beberapa pembahasan mengenai problematika pembelajaran bahasa Indonesia dari beberapa hasil penelitian yang telah dilakukan peneliti sebelumnya. Ada pun pembahasannya, yakni:

\section{a. Kurikulum}

Kurikulum 2013 adalah kurikulum pendidikan baru di Indonesia, yang baru saja diberlakukan oleh Kementrian Pendidikan dan Kebudayaan (Kemendikbud) Indonesia. Kurikulum 2013 ini masih baru dan sangat berbeda dari kurikulum sebelumnya sehingga banyak pro dan kontra yang timbul, dan hanya sekolah-sekolah yang ditunjuk saja yang mulai menggunakan kurikulum tersebut. Tujuan dari kurikulum baru ini adalah untuk memajukan pendidikan serta membenahi karakter pelajar di Indonesia. Kurikulum 2013 ini mencakup beberapa mata pelajaran, salah satunya adalah bahasa Indonesia. Penerapan kurikulum baru ini diharapkan dapat membuat siswa selalu berpikir kritis dan kreatif. Berdasar penjelasan di atas, salah satu materi pembelajaran bahasa Indonesia yang dapat membuat siswa berpikir kritis adalah pembelajaran yang berbasis masalah, atau sering disebut Problem Based Learning. Pada pembelajaran ini, siswa dihadapkan pada suatu masalah dan siswa akan memecahkan atau menguraikan masalah tersebut dengan berbagai cara, seperti berdiskusi dengan teman. Guru hanya berperan sebagai 'pemancing' agar siswa dapat menyelesaikan masalah tersebut. Contohnya pada materi teks anekdot, dalam membahas struktur dan ciri teks, guru 'memancing' siswa dengan menunjukkan salah satu contoh teks anekdot, kemudian siswa membedah struktur dan cirinya dengan membaca teks tersebut untuk kemudian didiskusikan bersama.

Selain Problem Based Learning, materi yang diterapkan kurikulum 2013 pada pembelajaran bahasa Indonesia adalah kontekstual. Jadi, siswa belajar dan memahami materimateri yang ada dan mengaitkannya dengan hal-hal sekitar yang berhubungan langsung dengan masyarakat. Contohnya adalah siswa dapat mengeluarkan pendapat dengan cara yang tepat, dengan bahasa yang baik dan benar. Pada materi teks anekdot misalnya, siswa diajak untuk menyampaikan pendapatnya dalam bentuk kritikan yang dikemas dalam bentuk teks anekdot. Dalam hal ini, tentu siswa harus mengetahui apa itu teks anekdot, bagaimana 
struktur dan bahasanya, apa saja ciri dan kaidah penulisannya, bagaimana contohnya, sebelum siswa dapat membuat teks anekdot. Meskipun sudah dijelaskan langsung oleh guru, secara tidak langsung siswa pasti juga akan mencari tahu sendiri supaya hasil tulisannya lebih baik.

Pembelajaran kurikulum 2013 juga mengacu pada pendekatan ilmiah, dengan adanya beberapa kegiatan, yaitu mengamati, menanya, menalar, mencoba, dan mengkomunikasikan. Siswa dipacu untuk mengamati lingkungan dan keadaan sekitar, mencari tahu apa yang terjadi dan mencoba mengkomunikasikannya. Hal ini selain mendorong siswa untuk berpikir kritis, juga mendorong siswa untuk menjadi proaktif. Seperti pada materi teks anekdot, guru mengarahkan siswa dengan memberi tugas mencari contoh teks anekdot, kemudian siswa akan merombaknya dengan mengganti subjek/tokohnya menjadi subjek/tokoh yang dekat dengan sekitarnya. Untuk melakukannya, siswa pasti akan mengamati terlebih dahulu, kemudian mencari tahu dan menalarnya, setelah itu, baru mencoba menulis untuk mengkomunikasikannya kembali.

Aspek penilaian pada kurikulum 2013 ini tidak hanya berdasar pada nilai kognitif atau kepintaran yang berdasarkan pada nilai tes, tugas atau ulangan. Tetapi juga berdasarkan aspek afektif dan juga psikomotor/praktik. Aspek afektif adalah penilaian tingkah laku siswa seharihari, bagaimana siswa bersikap dalam menerima pembelajaran, bertutur kata dengan sopan pada guru maupun sesama siswa, dan lain-lain. Sementara aspek psikomotor dinilai berdasarkan keaktifan siswa dalam kelas dan praktik yang dilakukan siswa pada tiap-tiap materi. Salah satu contohnya ada pada materi teks anekdot, yaitu siswa membacakan teks anekdot di hadapan siswa-siswa lain untuk kemudian dinilai.

Pada intinya, kurikulum 2013 akan sangat berperan dalam memajukan pendidikan dan membentuk karakter pelajar di Indonesia. Selain itu, kurikulum 2013 juga akan menghasilkan siswa-siswa yang memiliki pribadi yang cerdas dan mampu berpikir kritis dan kreatif serta peduli pada lingkungan sekitarnya, apabila dilaksanakan dengan baik dan benar, sesuai dengan kaidah dan peraturannya.

Berdasarkan hasil tinjau pustaka yang dilakukan oleh penulis maka dapat dijabarkan bahwa dalam pembelajaran bahasa Indonesia pada kurikulum 2013 ini terdapat beberapa problematika pembelajaran bahasa Indonesia, beberapa katagori problematika pembelajaran bahasa Indonesia yang peneliti deskripsikan sebagai berikut.

\section{b. Problematika Pembelajaran bahasa Indonesia}




\section{a. Problematika yang Dihadapi Guru dalam Proses Pembelajaran Bahasa Indonesia}

1. Format materi ajar dan tugas-tugas siswa, guru sepenuhnya mengacu pada materi yang terdapat dalam buku siswa dan petunjuk guru. Guru mengalami kesulitan dalam mengintegrasikan materi yang ada dalam buku siswa dan buku petunjuk guru sehingga bagi guru yang mengajarkan jadi kendala dalam menafsirkan maksud dalam buku siswa dengan yang ada dalam buku guru. Karena kedua buku tersebut tidak terintegrasi satu sama lain.

2. Guru belum begitu memahami penerapan pendekatan saintifik yang disarankan kurikulum 2013 sehingga pembelajaran bahasa Indonesia masih berpusat pada guru, bukan berpusat pada siswa. Hal ini terjadi karena siswa dan guru sudah terbiasa menggunakan metode mengajar dengan pola monoton, sulit bagi guru mengubahnya.

3. Guru dalam mengajarkan bahasa Indonesia kepada siswa belum memiliki perangkat penilaian otentik yang lengkap, dan belum menerapkan penilaian tersebut. Hal ini terjadi karena faktor ketidakpahaman guru dalam menerapkan penilaian tersebut atau karena guru malas dalam membuat dan memahami perangkat penilaian yang ada. Untuk itu, perlunya guru pada waktu mengajar mempersiapkan perangkat penilaian yang yang tepat sesuai karakteristik siswa.

4. Dalam mengajar, guru harus mampu menguasai berbagai macam model pembelajaran dengan baik. Kondisi di lapangan tidak semua guru mampu menguasai model-model pembelajaran yang diinginkan oleh kurikulum 2013.

5. Siswa dalam mengerjakan tugas yang terdapat dalam buku pegangan siswa, literatur, dan contoh sangat sedikit karena acuan buku lebih banyak kepada IPA sehingga guru kesulitan dalam mengembangkan materi pelajaran karena keterbatasan referensi materi mengenai ilmu alam tersebut. Guru hanya mengacu materi yang ada dalam buku siswa, kalau proses pembelajaran lebih baik, guru lebih dulu harus mencari informasi dari sumber lain seperti di internet. Apabila hal tersebut tidak dilaksanakan, guru tidak bisa langsung dengan percaya diri tampil di depan kelas.

6. Dalam buku pegangan siswa, apabila guru tidak membaca dan memahami (menganalisis) terlebih dulu buku pegangan siswa, guru juga akan kesulitan untuk mengkomunikasikan tugas-tugas kepada siswa. Untuk itu, guru diminta sebelum memerintahkan siswa untuk memahami dan mengerjakan tugas dalam buku tersebut, guru terlebih dahulu menjelaskan maksud kalimat (soal) yang tertulis dalam buku 
siswa serta menjelaskan contoh-contoh yang ada dalam buku. Apabila tidak dijelaskan, siswa akan mengalami kesulitan dalam mengerjakan tugas.

7. Karena banyak tugas yang harus dikerjakan oleh siswa, guru harus juga banyak menggunakan waktu untuk mengoreksinya. Untuk itu, tinggal kesediaan guru dan ketekunan guru dalam melaksanakan tugas tersebut. Karena penilaian otentik mengacu pada tiga ranah penilaian, yaitu penilaian sikap, pengetahuan, dan keterampilan. Yang menjadi kendala, apabila guru tidak melaksanakan ketiga konsep penilaian tersebut dalam proses pembelajaran di kelas.

\section{b. Problematika Siswa dalam Pembelajaran bahasa Indonesia}

1. Siswa memiliki keberagaman kompetensi, pengetahuan, dan keterampilan sehingga guru harus memiliki kesabaran untuk membimbing siswa sampai tuntas, baik siswa memiliki kemampuan berpikir cepat, sedang, dan lambat. Kesemua kompetensi tersebut dalam kurikulum 2013 harus terayomi dengan baik dan sesuai dengan kondisi siswa yang ada di kelas. Apabila hal tersebut tidak terlaksana, komponen penting dalam kurikulum 2013 tidak akan tercapai maka siswa mengalami kendala dalam mengikuti pelajaran. Solusinya pada saat proses belajar-mengajar, guru harus jeli dalam melihat potensi siswa yang ada.

2. Kemampuan anak yang rata-rata kecerdasannya lambat, guru perlu memperjelas materi dengan dengan membimbing siswa secara penuh, sehingga terkesan guru lebih aktif, bukan siswanya yang aktif. Materi pelajaran yang ada dalam buku siswa, masih seputar tema pelajaran I, "Gemar Meneroka Alam Semesta". Lambatnya penggunaan buku siswa tersebut, telah diakui oleh guru yang bersangkutan bahwa hal itu disebabkan lemahnya potensi kecerdasan siswa dalam memahami dan menyerap pelajaran dalam buku siswa.

3. Materi yang ada dalam buku siswa cukup sulit bagi siswa yang wawasan pengetahuannya terbatas atau siswa yang daya nalarnya katagori $\mathrm{C}$ (lambat berpikir) untuk memahami buku teks pelajaran, siswa katagori ini harus dibantu oleh guru secara penuh agar siswa dapat memahami pelajaran dengan baik dan sesuai dengan tuntutan kurikulum.

4. Perlu mengintegrasikan materi yang diajarkan dengan pemahaman dan pengetahuan yang dimiliki siswa.

5. Adanya istilah teknis yang tidak umum dan sulit dipahami siswa, perlu dijelaskan oleh guru secara lebih lengkap agar siswa lebih memahami materi pembelajaran. Bisa 
juga disarankan oleh guru agar siswa lebih dulu membaca buku-buku yang relevan dengan materi ajar sehingga proses pembelajaran di kelas menjadi lebih hidup dan siswa menjadi aktif.

6. Tidak adanya petunjuk yang jelas untuk menggunakan buku siswa dengan baik pada waktu proses belajar-mengajar. Guru yang tidak kreatif hanya mengikuti materi sesuai dengan apa yang dalam buku siswa, sehingga guru kesulitan memahami soal atau tugas yang ada dalam buku siswa.

7. Adanya ketidakefektifan waktu pada saat siswa menjawab soal dalam buku siswa, waktu terlalu banyak. Siswa masih terobsesi pada metode pembelajaran dengan sistem KTSP, guru lebih berperan aktif menjelaskan.

8. Dalam kurikulum baru, siswa ditekankan pada keaktifan siswa dalam melaksanakan tugas-tugas karena pada kurikulum 2013 ini ada banyak tugas yang dilakukan oleh siswa. Siswa yang tidak terbiasa dengan tugas-tugas atau latihan yang selalu ada dalam kurikulum ini, dia akan merasa keberatan atau paling tidak ada semacam keluhan.

9. Karena cakupan materi yang ada pada buku siswa lebih banyak materi ilmu alam, ada saja komentar dan pertanyaan siswa. Mengapa bahasa Indonesia, belajar IPA tentang binatang? Nah ini yang sering ditanyakan oleh siswa kepada gurunya sehingga guru sulit menjawabnya karena memang itu ada di kurikulum. Hal ini adalah tuntutan yang harus diselesaikan. Yang lebih parah lagi apabila guru kurang menguasai ilmu alam sehingga guru sulit melakukan implementasi atau memberikan jawaban pertanyaan siswa yang menyangkut ilmu pengetahuan alam ini.

10. Masalah lain seperti kesiapan siswa dalam menelaah dan mempelajari materi buku pegangan siswa. Karena materinya harus betul-betul dipahami dan siswa harus konsentrasi pada waktu membaca. Apabila siswa tidak konsentrasi, siswa akan mengalami kesulitan dalam memahami teks yang dibaca akibatnya akan berdampak pada kurang mampunya siswa mengerjakan tugas-tugas (soal-soal) yang ada dalam buku paket siswa. Solusinya sebagai guru tidak boleh melepaskan tanggung jawab bimbingan kepada siswa, karena ada guru membiarkan begitu saja siswa mengerjakan tugas, siswa kebingungan dalam mengerjakan tugas-tugas dan tidak dipandu oleh guru.

11. Setiap format latihan harus ditafsirkan oleh guru terlebih dahulu, baru disuguhkan kepada siswa. Tujuannya agar siswa lebih memahami tugas yang dikerjakannya apabila tugas yang dikerjakan dipahami siswa, guru tidak sulit lagi dalam 
membimbing siswa mengerjakan. Siswa akan mengerjakan secara mandiri. Sampai tugas tersebut selesai. Yang jadi kendala adalah apabila guru dan siswa belum mampu untuk menafsirkan permasalahan (soal) yang ada dalam buku siswa, sehingga guru dan siswa sama-sama meraba-raba alternatif jawaban yang benar sesuai dengan kemampuan dan pengetahuan yang dimiliki oleh guru.

12. Siswa harus sering berinteraksi dengan materi yang dihadapinya, tidak lagi bersifat teori tetapi harus real (nyata), untuk itu guru harus membawa contoh yang nyata tentang materi ajar yang diperagakan kepada siswa agar siswa lebih memahami.

13. Siswa dituntut untuk kreatif dengan banyak bertanya dalam mengerjakan tugas-tugas pada buku pegangan siswa kepada guru. Apabila tidak, siswa akan mengalami kesulitan dalam mengerjakan tugas, dan menjawab pertanyaan yang ada dalam buku siswa.

14. Bila hendak mengetahui siswa yang cerdas dan kreatif akan terlihat dengan kecepatan dan ketepatannya dalam menjawab-soal-soal yang ada dalam buku siswa.

\section{c. Problematika Materi dan Media dalam Pembelajaran Bahasa Indonesia}

1. Media berupa LCD masih terbatas di sekolah sehingga tidak semua kelas dapat menggunakan media tersebut ketika proses pembelajaran berlangsung.

2. Sarana belajar penunjang berupa buku-buku penunjang yang ada di perpustakaan (sebagai referensi) masih terbatas. Hal ini membuat belum banyak memberikan wawasan atau pengetahuan baru bagi siswa. Siswa menjadi kesulitan untuk memahami bingung untuk menafsirkan materi yang ada dalam buku siswa.

3. Materi ajar dalam buku teks siswa, sebagian ada yang sulit dipahami oleh siswa. Hal ini disebabkan siswa belum terbiasa dengan masalah yang dikemukakan dalam buku pegangan siswa tersebut.

4. Adanya sebagian materi dalam buku siswa yang tidak sesuai dengan usia dan karakteristik siswa. Contoh teks prosedur kompleks tentang pembuatan Surat Izin Mengemudi (SIM), kendalanya siswa kelas X masih berumur di bawah 17 tahun, sedangkan SIM baru bisa dibuat apabila siswa berumur 17 tahun ke atas.

\section{d. Problematika Penilaian dalam Pembelajaran Bahasa Indonesia}

Penilaian adalah proses pengumpulan dan pengolahan informasi untuk mengukur pencapaian hasil belajar peserta didik. Penilaian merupakan serangkaian kegiatan untuk memperoleh, menganalisis, dan menafsirkan data tentang proses dan hasil belajar peserta 
didik yang dilakukan secara sistematis dan berkesinambungan, sehingga menjadi informasi yang bermakna dalam pengambilan keputusan. Penilaian dapat dilakukan selama pembelajaran berlangsung (penilaian proses) dan setelah pembelajaran usai dilaksanakan (penilaian hasil/produk).

1. Guru masih belum memiliki perangkat penilaian otentik secara lengkap yang diinginkan oleh kurikulum karena aspek penilaian ini belum sepenuhnya dilaksanakan oleh guru. Kalau pun dilaksanakan, penilaiannya hanya sebagian atau hanya sebatas penilaian sikap, sedangkan penilaian yang lain belum mengemuka. Hal ini dikarenakan waktu yang terbatas dengan format 2 x 40 menit, (untuk 1 x pertemuan). Pada saat mengajar, guru asyik membimbing siswa sehingga waktu untuk menerapkan penilaian terbatas bahkan ada yang tidak sempat.

2. Terlalu banyaknya format prosedur penilaian kepada siswa membuat guru sulit merangkum penilaian secara keseluruhan.

3. Waktu untuk melakukan proses penilaian sangat sedikit. Hal ini biasa dilakukan guru pada saat pelajaran mulai berakhir. Waktu yang tersedia sangat singkat, tidak semua siswa dapat dinilai segala aktivitasnya pada waktu pembelajaran tersebut.

\section{SIMPULAN}

Berdasarkan paparan yang telah diungkapkan seblmnya bahwa dapat ditarik kesimpulan bahwa makala ini memiliki beberapa permasalahan yang telah ditemukan, permasalahan tersebut dijabarkan dalam beberapa faktor yang mengemuka dan ditentukan di lapangan pada saat meneliti. Beberapa faktor tersebut ada berupa permasalahan seperti faktor guru yang mengajar, faktor siswa, dan faktor materi pembelajaran.

Kendala atau problematika pembelajaran ditinjau dari faktor guru yang mengajar. Bila ditinjau dari faktor guru yang mengajar, permasalahan yang timbul adalah kurangnya kesiapan guru dalam menerapkan kurikulum 2013 dan kurang sumber daya guru yang mampu menterjemahkan dan mampu menafsirkan sesuai kehendak kurikulum 2013. Guru kebingungan dalam menerapkan kurikulum yang diinginkan oleh kurikulum 2013. Hal ini karena minimnya persiapan dan kompetensi guru dalam mengajar yang sesuai dengan kehendak kurikulum. Guru hanya merabaraba langkah-langkah yang diinginkan oleh kurikulum. Selain itu, tidak semua guru mengikuti pelatihan kurikulum 2013, kalau pun ada pelatihan, waktunya cukup singkat dan tergesa-gesa, sehingga tidak memenuhi target yang sesuai dengan apa yang diinginkan dalam kurikulum. 


\section{DAFTAR RUJUKAN}

Driana, Elin. Gawat Darurat Pendidikan. Kompas, 14/12/2012.

Nasution, S. 1996. Metode Penelitian Naturalistik Kualitatif. Bandung: Tarsito.

Sudaryanto. 1993. Metode dan Teknik Analisa Bahasa, Pengantar Penelitian Wahana Kebudayaan secara Linguistik. Yogyakarta: Duta Wacana University Press. 